DOE/NASA CONTRACTOR REPORT

DOE/NASA CR- 150828

\title{
PROTOTYPE SOLAR HEATING AND COOLING SYSTEMS
} (Monthly Progress Reports)

Prepared from documents furnished by

AiResearch Manufacturing Company of California

2525 West 190th Street

Torrance, California 90509

Under Contract NAS8-32091 with

National Aeronautics and Space Administration

George C. Marshall Space Flight Center, Alabama 35812

For the U. S. Department of Energy

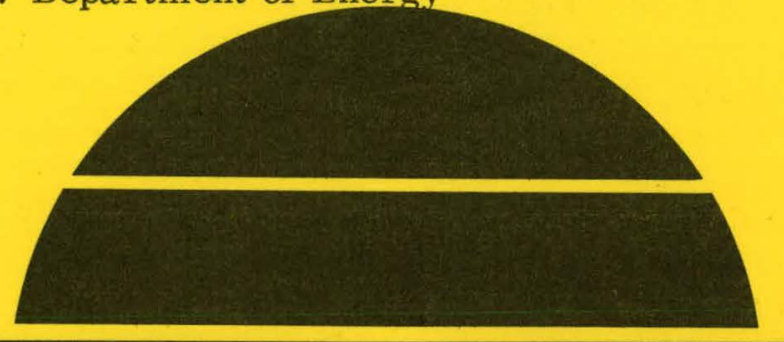

\section{U.S. Department of Energy}




\section{DISCLAIMER}

This report was prepared as an account of work sponsored by an agency of the United States Government. Neither the United States Government nor any agency Thereof, nor any of their employees, makes any warranty, express or implied, or assumes any legal liability or responsibility for the accuracy, completeness, or usefulness of any information, apparatus, product, or process disclosed, or represents that its use would not infringe privately owned rights. Reference herein to any specific commercial product, process, or service by trade name, trademark, manufacturer, or otherwise does not necessarily constitute or imply its endorsement, recommendation, or favoring by the United States Government or any agency thereof. The views and opinions of authors expressed herein do not necessarily state or reflect those of the United States Government or any agency thereof. 


\section{DISCLAIMER}

Portions of this document may be illegible in electronic image products. Images are produced from the best available original document. 
NOTICE

This report was prepared to document work sponsored by the Unfted States Government. Nelther the United States nor 1ts agents the Unfted States Department of Energy, the Unfted States National Aeronaut1cs and Space Adminietration, nor any federsl employees, nor any of thefi contractors, sulcurtractors or the1r employees, make any warranty, express or 1ifflitd, or assume any legal 11ability or responsibility for the accuracy, completeness, or usefulness of any informat1on, apparatus, product or process disclosed, or represent that its use would not Infringe privately owned rights. 


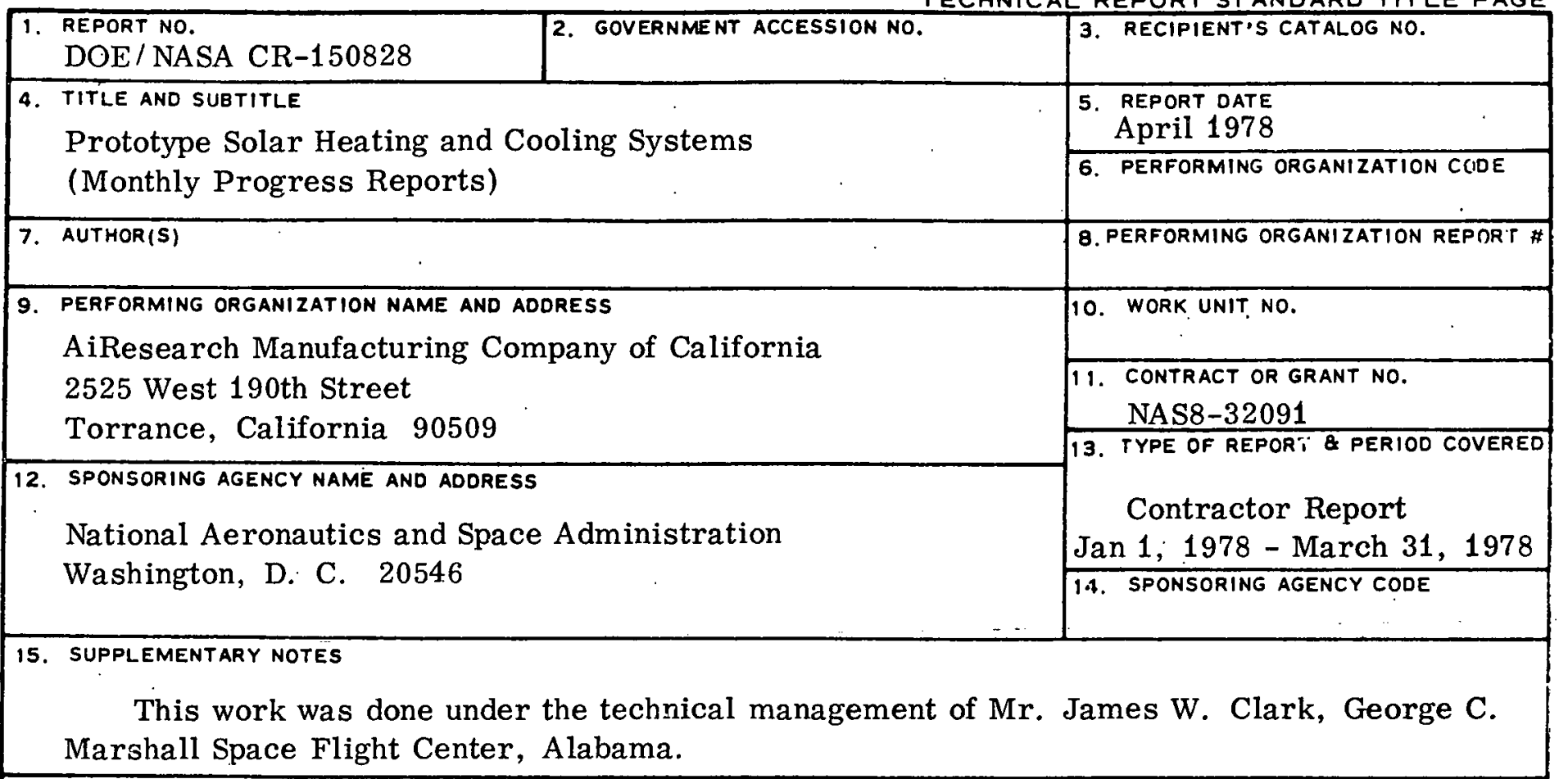

16. ABSTRACT

This report is a collection of monthly status reports from the AiResearch Manufacturing Company covering the period January 1, 1978, through March 31, 1978. AiResearch is developing eight prototype solar heating and cooling systems. This effort calls for the development, manufacture, test, system installation, maintenance, problem resolution, and performance evaluation. The systems are $3-, 25-$, and $75-$ ton size units.

Cost information has been removed from these reports.

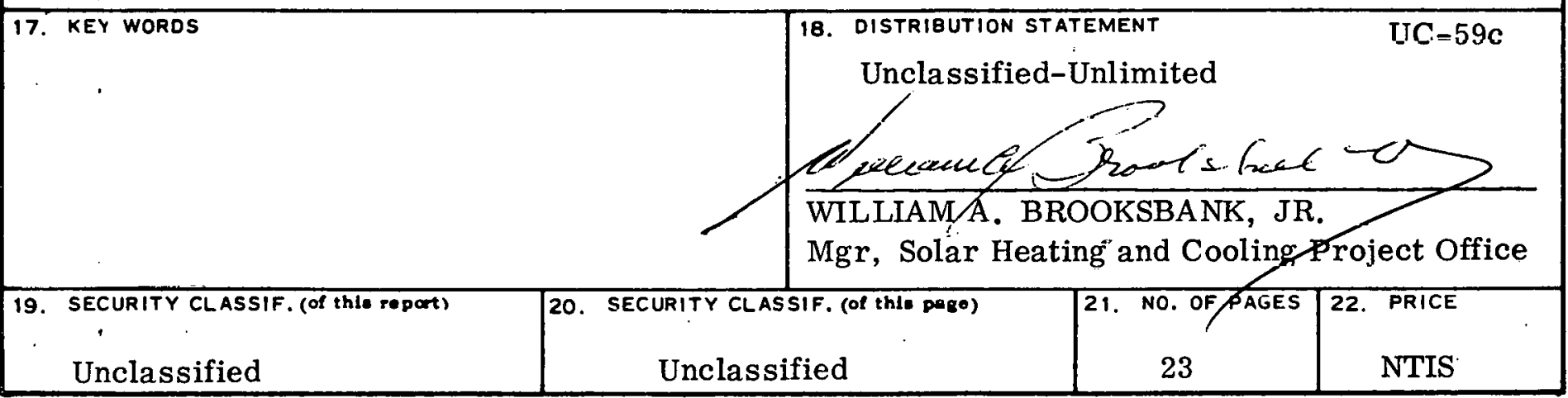


THIS PAGE

\section{WAS INTENTIONALLY LEFT BLANK}


Section A - Fourteenth Monthly Status Report

January 1 through March 31, 1978

Section B - Fifteenth Monthly Status Report

February 1 through February 28, 1978

Section C - Sixteenth Monthly Status Report

March 1 through March 31, 1978

c-1

This report wotice -

sponsored by the prepared as an account of work

United States nor the United Sint Da. Nesther the

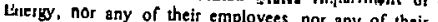

contractors, subcontractors, or hes, hor any of their

any warranty, express or implied, employees, makes

liability or responsibility for the ansiames any legal

or uselulness of any in !or the arrinracy, oompletentéso

process disclosed, or informativin, apparatus, product or

process disclosed, or represents that its use would not
infringe privately owned rights.

infringe privately owned rights. 
PART A

\section{Fourteenth Monthly Status Report Data Requirement No. 500-11}

\section{SOLAR HEATING AND COOLING SYSTEMS DESIGN AND DEVELOPMENT}

Contract NAS8-32091

$76-13110(14)$

February 10, 1978

Approved by

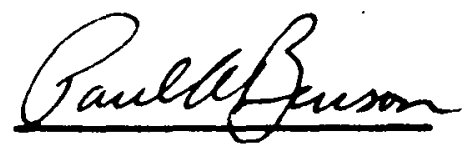

P. A. Benson

\section{Prepared for}

George C. Marshall Space Flight Center

National Aeronautics and Space Administration

Marshall Space Flight Center

Huntsville, Alabama 35812

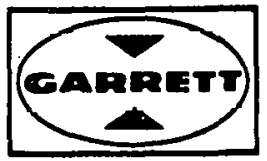

AIRESEARCH MANUFACTURING COMPANY

OF CALIFORNIA 
INTRODUCTION

This is the fourteenth monthly status report prepared by AiResearch Manufacturing Company of California under Contract NAS8-32091 for the National Aeronautics and Space Administration Marshall Space Flight Center (MSFC). The report summarizes activities from January 1, to January 31, 1978.

For simplicity in reporting, activities are reported by subject matter. rather than by WBS item number.

MEETINGS, REVIEWS, AND MAJOR EVENTS

Activities during January were as follows:

- A program review meeting was held at AiResearch on January 10 and 11 , 1978 with NASA. representatives James Clark, Ray Spink and Frank Nola in attendance.

- Mssrs. James Clark and Larry Marshall visited AiResearch on January 16, 1978, for a program orientation meeting.

- A site installation meeting was held at the Las Vegas City Engineer's Office on January 24, 1978 regarding the Stewart and Mojave Recreational Center solar heating/cooling installation.

PROGRAM PLANNING AND CONTROL

NASA Coordination Activities

The discussion meeting with NASA representatives Ray Spink and Frank Nola centered on (1) storage tank geometry and thermal energy storage, (2) expansion tanks., (3) insulation and (4) motor controller and motor. The AiResearch storage tank design was reviewed with regard to fluid stratification and short circuiting.

NASA and AiResearch arrived at mutually agreeable revised supply and return nozzle locations for the collector and heat pump. AiResearch concurred with NASA that there he a temperature probe to more properly meosurc the tenk temperature distribution. The storage tank drawing was marked up to show temperature probe locations and was forwarded to NASA. Mr. Spink agreed with AiResearch that the expansion tank need not be insulated.

Updates of Development, Manufacturing and Delivery Schedules

Mr. James Clark pointed out some inconsistencies in the Figures $1-2,2-2$, 2-3 and 4-11 schedules presented in the Sixth Quarterly Report. It was decided to update the Figure $1-2$ and 4-1I schedules to include activities of January while correcting the inconsistencies. These schedules appear in this report as Figures 1 and 2, respectively.

The corrected Figures $2-2$ and $2-3$ are included at the end of this report as DR500-10 errata sheets, since program costs are not ordinarily a part of the monthly progress reports. 


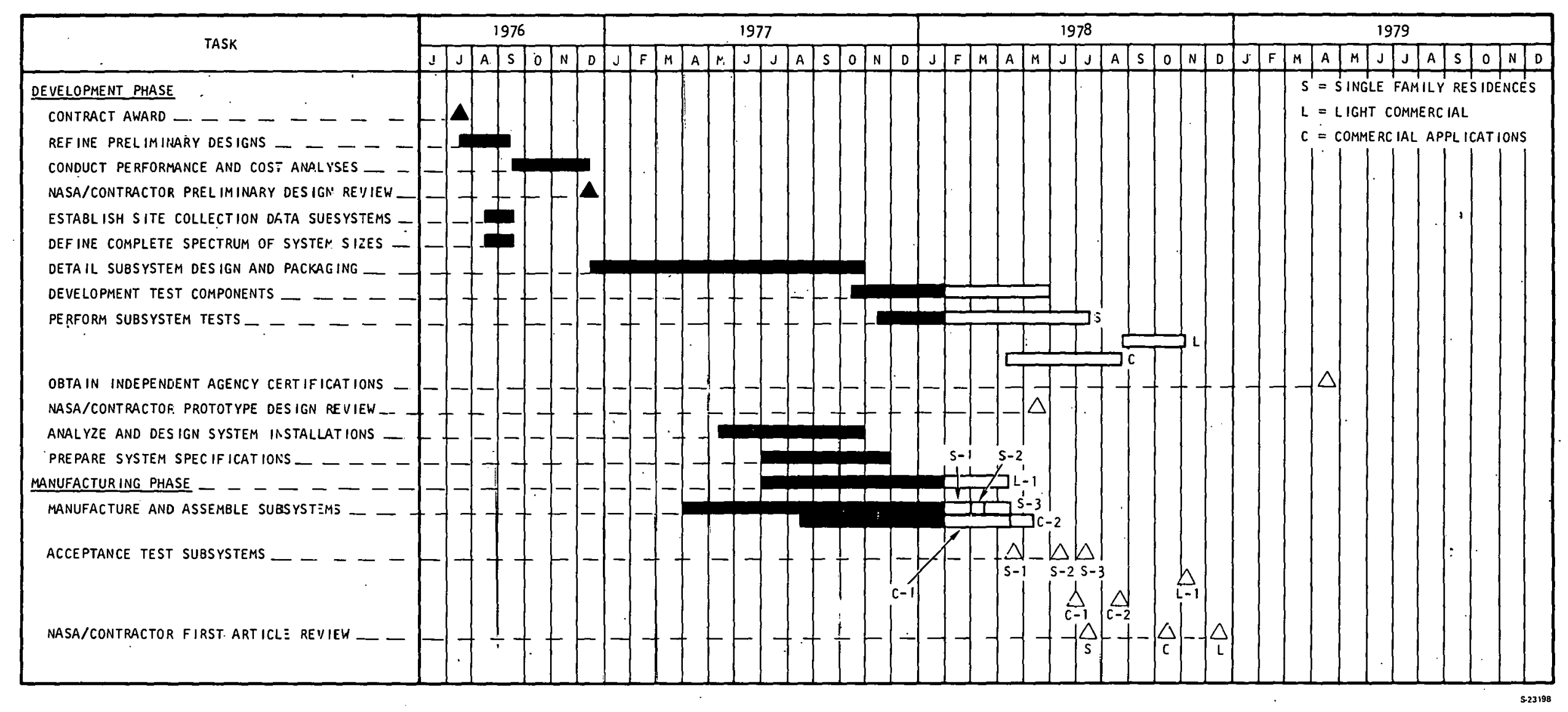




\begin{tabular}{|c|c|c|c|c|c|c|c|c|c|c|}
\hline SIZE & UNIT & $\begin{array}{l}\text { TURBOCOM- } \\
\text { PRESSOR } \\
\end{array}$ & $\begin{array}{c}\text { MOTOR } \\
\text { CONTROL } \\
\end{array}$ & $\begin{array}{l}\text { FREON } \\
\text { PUMP } \\
\end{array}$ & $\begin{array}{c}\text { HEAT\% } \\
\text { PUMP } \\
\text { COMPLETE } \\
\end{array}$ & $\begin{array}{l}\text { START } \\
\text { TEST } \\
\end{array}$ & $\begin{array}{l}\text { TEST } \\
\text { TIME, } \\
\text { WEEKS } \\
\end{array}$ & $\begin{array}{c}\text { TEST } \\
\text { COMPLETE } \\
\end{array}$ & $\begin{array}{l}\text { SHIP } \\
\text { DATE } \\
\end{array}$ & $\begin{array}{l}\text { INTEADED } \\
\text { SITE } \\
\end{array}$ \\
\hline 3 TON & $\begin{array}{l}\# 1 \\
\# 2 \\
\# 3 \\
\# 4\end{array}$ & $\begin{array}{l}\text { Shipped } \\
3-1 \\
4-1 \\
\text { On Stop }\end{array}$ & $\begin{array}{l}\text { Shlpped } \\
3-1 \\
4-1\end{array}$ & $\begin{array}{l}2-15 \\
3-1 \\
4-1\end{array}$ & $\begin{array}{l}3-1 \\
3-15 \\
4-14\end{array}$ & $\begin{array}{l}3-1 \\
4-22 \\
6-17\end{array}$ & $\begin{array}{l}8 \\
8 \\
4 \\
4\end{array}$ & $\begin{array}{l}4-22 \\
6-17 \\
7-15\end{array}$ & $\begin{array}{l}5-6 \\
7-1 \\
8-1\end{array}$ & $\begin{array}{l}\text { Harrisonburg, VA. } \\
\text { Lawrenceburg, TN. } \\
\text { Allaire Park, N.J. } \\
\text { Novato, CA. }\end{array}$ \\
\hline $25 \mathrm{TON}$ & $\begin{array}{l}\# 1 \\
\# 2\end{array}$ & $\begin{array}{l}2-15 \\
\text { On Stop }\end{array}$ & $2-15$ & $3-3$ & $4-12$ & $8-27$ & $\begin{array}{l}10 \\
6\end{array}$ & $11-6$ & $11-20$ & $\begin{array}{l}\text { St. Louis, Mo. } \\
\text { Los Angeles, CA. }\end{array}$ \\
\hline 75 TON & $\begin{array}{l}\# 1 \\
\# 2\end{array}$ & $\begin{array}{l}2-15 \\
3-15\end{array}$ & $\begin{array}{l}2-15 \\
5-1\end{array}$ & & $\begin{array}{l}4-6 \\
5-15\end{array}$ & $\begin{array}{l}4-7 \\
7-2\end{array}$ & $\begin{array}{l}12 \\
8\end{array}$ & $\begin{array}{l}7-1 \\
8-27\end{array}$ & $\begin{array}{l}7-15 \\
9-3\end{array}$ & $\begin{array}{l}\text { Houston, TX. } \\
\text { Las Vegas, NV. }\end{array}$ \\
\hline
\end{tabular}

$\frac{a}{\frac{a}{w}}$

Figure 2. Heat Pump Delivery Schedule 


\section{Site Activities}

\section{Allaire State Park Site}

a. The pressure distribution problem in headers of the solar collector panels was reviewed.

b. The solar collector panel arrangement was established ( 2 groups of 5 parallel collectors connected in series for a bank of 10).

c. The decision to use ethylene glycol as the heat transfer fluid. in the collector system was reaffirmed.

d. The revised Daystar specifications were reviewed and forwarded to Mueller, Timmerman, and JBA for the Allaire, Houston, and Las Vegas sites, respectively.

e. The collector mounting structure is now under preliminary review.

f. The site plans were reviewed.

2. Lawrenceburg Site

a. A decision was made to install ten solar collectors in parallel per bank.

3. Las Vegas Site

a. Vendors were contacted to submit quotes on the 600 -gallon preheater.

b. A firm quote was received from Tranter, Inc. fur the 600-gallon preheater which was considered too expensive.

c. Vendors werc contacted regarding the alferhate plan uf using (4) l20-gallon straight DHW tanks.

d. The acceptability of the alternative plan was cleared with JBA.

e. JBA was directed to call out four Solarstream 120-gallon DHW tanks in liau of the 600-gallon preheater previously planned.

f. Site installation meeting was held in Las Vegas January 24, 1970:

g. A preliminary review of the collectur mounting structure per sketches rccelved at sile illstallation meeting was initiated.

h. Site plans were reviewed.

3. Houston Site

a. The coll lector panel mounting structure was reviewed.

b. Site plans were reviewed. 


\section{Harrisonburg Site (Dunham-Bush)}

a. The collector mounting structure is under preliminary review.

b. Site plans were reviewed.

Site C.P. Status

Table I that follows summarizes Garrett costs incurred thru January 1 on the various test sites.

\section{Program Documentation}

The following documents were prepared in accordance with the requirements of Appendix A of the Statement of Work:-

a. Sixth Quarterly Status Report 76-13296(6), dated January 10, 1978 (DR500-10)

(b) Quarterly Contractor Financial Management Report (DR500-27), dated January $20 ; 1978$

Other publications were submitted to the parties listed during January as tabulated below:

\section{Submittal}

Date

$1-4-78$

$1-17-78$

1-19-78 T. King, Mueller

1-26-78 J. Clark,

$1-27-78$
G. Neff, TEI Assóciates NASA/MSFC

To

J. Clark, NASA/MSFC

G. Neff, TEI, and

R. Joeckel, JBA

3

1

\section{Subject}

Dunham-Bush Test House System Information Memo

University of Houston Developmental Arts Building Memo concerning (1) solar panel mounting structure, (2) storage tank drawings and (3) direct-heating heat exchanger catalogue sheets

Allaire Site Memo discussing (1) solar collector panel arrangement and (2) use of ethylene glycol in the solar collectors

Minutes of the Las Vegas Site Installation Meeting of January 24, 1978

Daystar Procurement Specifications 1200-900-001 and 1200-901-001 
Power requirements were being determined for each of the electrical components for all three system sizes for use in SDAS instrumentation plans. The analysis is continuing into February.

\section{SYSTEM DEVELOPMENT.}

The activities reported below involve heat pump component design, fabrication and testing, and heat pump package development.

\section{Component Design, Fabrication and Test}

1. Turbomachine

\section{(a) 3-Ton Unit}

One unit has been shipped to Dunham-Bush for installation and test in their system. The second unit is in the system rig at AiResearch for performance testing of the turbine. Upon completion of these tests (within 2 weeks), the unit will be shipped. Parts for the third unit are being returned from Dunham-Bush; they were being used as a mockup. This unit will be ready to ship before March, 1978.

\section{(b) 25-Ton Unit}

January was spent conducting performance tests in the heating mode. This testing provided data throughout the operating range. The unit to be shipped to Dunham-Bush by mid-February is in the system rig to be tested. No other 25-ton units are scheduled for shipment.

\section{(c) 75-Ton Unit}

The first 75-ton unit was assembled and dellvered to the electrical labu oratory for checkout with the controller (see Figures 1 and 2). It was discovered that an error had been made in winding the stator. Drawing changes have been made to correct this error and stators are being rewound. The unit with reworked stator assembly will be available for test February 15. If the testing is successful, this unit can be delivered to Dunham-Bush by March, 1978.

The second deliverable unit is being assembled and will be available for checkout tests by March also.

\section{Mocor Controller}

\section{(a) 3-Ton Controller}

Interface testing of the 3-ton controller has been satisfactorily concluded and the first production controller has been shipped to Dunham-Bush.

Fabrication of production controllers No. 2 and No. 3 is continuing. These controllers are both 75 percent complete. 


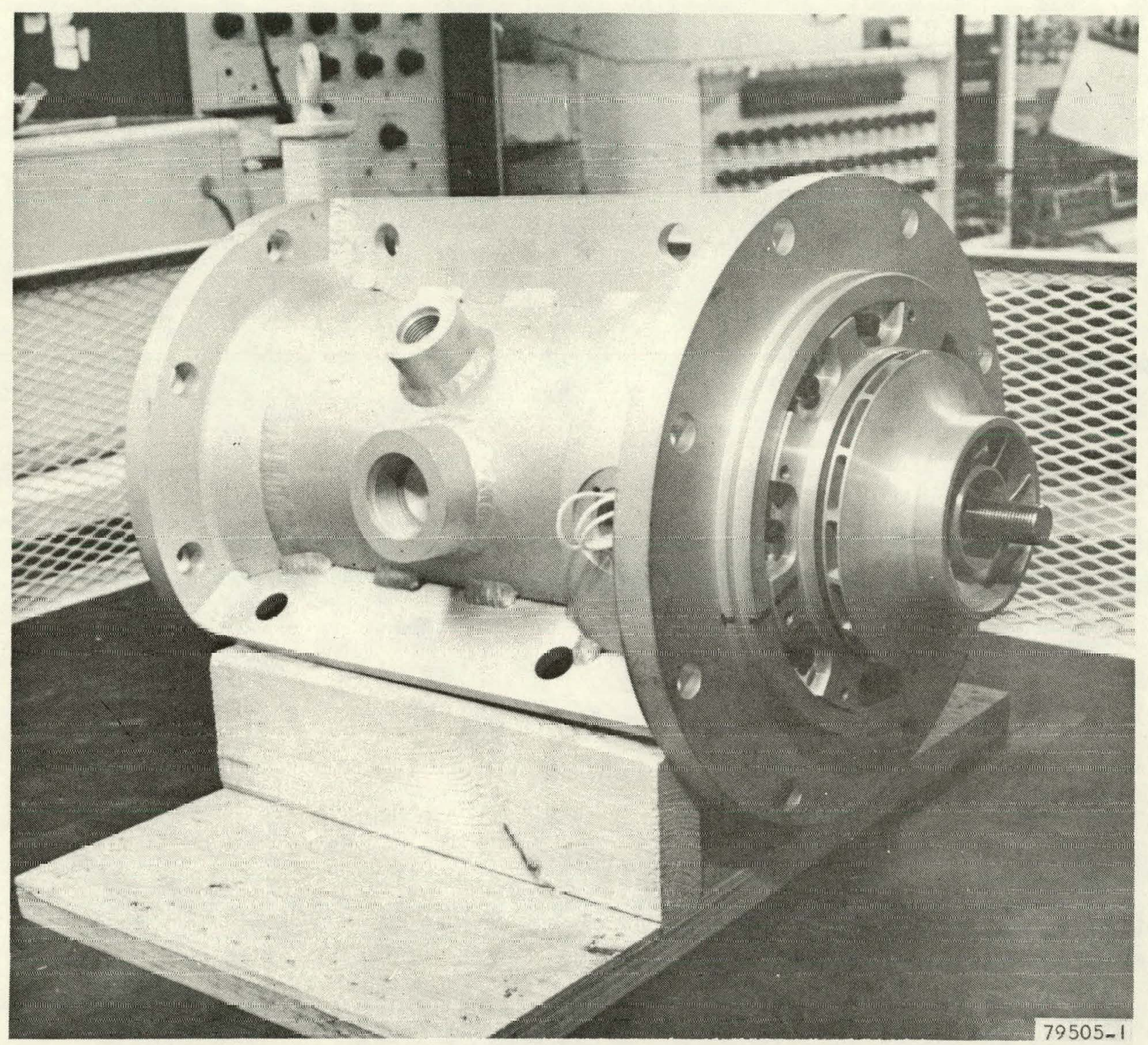

Figure 3. 75-Ton Protolype Turbomachine Viewed from Turbine End 


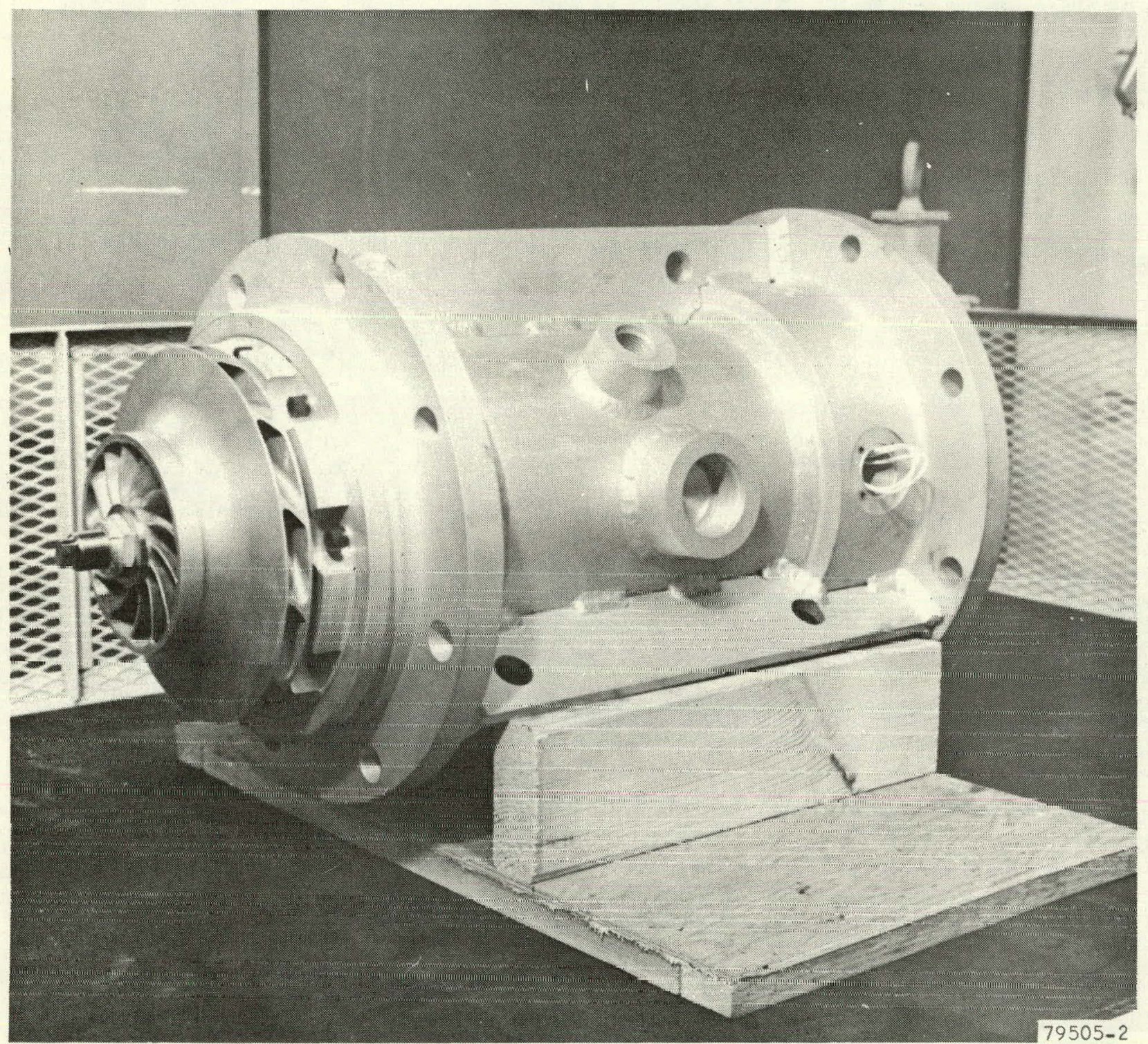

Figure 4. 75-Ton Prototype Turbomachine Viewed from Compressor End 
(b) 25-Ton Controller

The 25-ton controller breadboard has been successfully operated closedloop on speed at nominal load.

The fabrication and testing of the first production controller with an unloaded motor is 100 percent complete. This controller will now be tested at maximum speed and nominal load prior to shipment.

\section{(c) 75-Ton Controller}

The fabrication of the 75-ton production controller is 98 percent complete. This controller has been 95 percent tested with a 25-ton system motor.

An analytical study of the firing angle vs load current witl be done to determine the optimum firing angle for the inverter.

\section{System Controller}

Two system controllers have been completed. Three additional assemblies are complete except for the interconnecting cables. A system controller was successfully interfaced with the 3 -ton motor controller and motor during the laboratory system test.

Thermistor probe configurations and quantities were defined and probe fabrication will be initiated.

4. R-11 Liquid Pump

(a) 3-Ton Unit February.

Three pump units have been ordered; delivery is scheduled for late in

\section{(b) 25-Ton Unit}

The endurance test of the 8-vane pump, begun in December, has accrued 860 hours without change in the pump performance. Detail drawings were completed and thuee production pumps were ordered; delivery is anticipated in early March. 


\section{Heat Pump Design, Fabrication and Test}

\section{Design}

Designs and drafting had been completed when it was determined that an external heat exchanger was needed in the circulation system. As a result, the piping drawings have been revised for the 25-ton and 75-ton units.

To date, Dunham-Bush still does not have a reversing valve for the 75-ton unit. At present, elimination of the reversing valve and use of the turbocompressor for cooling only is being considered.

\section{Prototype Fabrication}

(a) Model 2201288-HC-83 Heating/Cooling Unit

The turbocompressor and the motor controller for the 3-ton heat pump were received by Dunham-Bush on January 24, 1978. The turbocompressor has been installed and piped in place of the mock-up. The package is nearly complete except for receipt of the R-II pump.

Two four-way reversing valves have been received from Product Engineering and one is assembled on the model.

(b) Model $2201288-\mathrm{HC}-825$ Heat ing/Cooling Unit

The piping on the first 25-ton heat pump has been revised to provide for the external heat exchanger in the circulation system.

Control boxes for the switching relays for the 25-ton heat pumps are being fabricated.

\section{(c) Model 2201288-HC-2075 Heating/Cooling Unit}

The frames for the two 75-ton heat pump packages have been fabricated and assembled. All parts have been ordered, and are being installed as they are received.

\section{Test Activities}

All test setups are operational and await the prototype test packages. However, Dunham-Bush feels that the schedules published in the Sixth Quarterly Report are overly optimistic. 


\title{
Fifteenth Monthly Status Report Data Requirement No. 500-11
}

\section{SOLAR HEATING AND COOLING SYSTEMS DESIGN AND DEVELOPMENT}

\author{
Contract NAS8-32091
}

76-13110(15)

March 10, 1978

Approved by

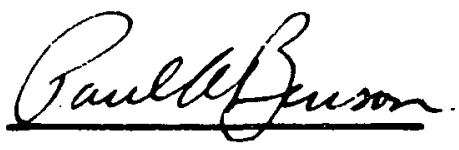

P. A. Benson

Prepared for

George C. Marshall Space Flight Center National Aeronautics and Space Administration Marshall Space Flight Center

Huntsville, Alabama $\mathbf{3 5 8 1 2}$

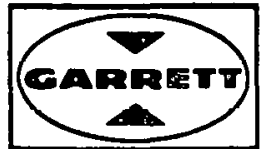

AIRESEARCH MANUFACTURING COMPANY

OF CALIFORNIA 


\section{INTRODUCTION}

This is the fifteenth monthly status report prepared by AiResearch Manufacturing Company of California under Contract NAS8-32091 for the National Aeronautics and Space Adminstration Marshall Space Flight Center (MSFC). The report summarizes activities from February 1, to February 28 , 1978.

For simplicity in reporting, activities are reported by subject matter rather than by WBS item number.

MEETINGS, REVIEWS, AND MAJOR EVENTS

Activities during February were as follows:

- Review meetings were held at the Dunham-Bush and Lawrenceburg test sites. Paul Benson and Paul Walker of AiResearch attended the latter meeting while Robert Susag and Paul Benson visited Dunham-Bush.

- Testing of the 3-ton heat pump was initiated this month. Test runs were made at $60,000 \mathrm{rpm}, 78,000 \mathrm{rpm}$ and $81,500 \mathrm{rpm}$ when a transistor burned out, terminating the test.

- After the motor controller was repaired, a second run was made with a ventillated controller, but while investigating a surge condition, the test technician inadvertantly shorted a transistor with a temperature probe.

- A review meeting was held at Las Vegas at which the latest drawings of the site installation were reviewed. Paul Benson and Paul Walker attended.

PROGRAM PLANNING ANO CONTROL

Program control activities were concentrated on cost reduction measures. All activities with the exception of instrumentation planning and program coordination were abbreviated.

\section{Site Activities}

\section{Allaire State Park Site}

Revision A of the Instrumentation System Planning Information (ISPI) forms were submitted. The revision was made (a) to delete all dual-element temperature probes, (b) to specify all copper tubing in lieu of copper and galvanized steel for the system, (c) to add information requested by SDAS personnel at NASA/MFSC, and (d) to update the system and its instrumentation to concur with latest agreements between NASA, the site owner and AiResearch.

2. Lawrenceburg Site

After the site review meeting on February 17, the following action items were implemented. 
- Solar panel mounting structure details were resolved

Panel connecting hose specifications were revised

- A partial list of long-lead time items was issued

3. Las Vegas Site

Revision C of the ISPI forms were submitted on February 16. The same changes as noted for the Allaire State Park site were incorporated, with the exception of the copper tubing.

An attempt was made to review the latest drawings for the site installation at the February 23 meeting. This attempt was limited in value, since the Las Vegas mechanical engineer was unable to attend.

4. Houston Site

An analysis of the expansion tank for the storage tank system was made and submitted to NASA. Revision B of the ISPI forms was begun. Estimated completion of the ISPI is March 10, 1978. Changes were nearly identical to those for Las Vegas.

\section{Program Documentation}

The following documents were prepared in accordance with the requirements of Appendix A of the Statement of Work:

a. Fourteenth Monthly Status Report 76-13110( 14), dated February 10,1978 (DR500-11).

b. Quarterly Contractor Financial Management Report (DR500-27)

0 ther publications were submitted during February to the parties:listed as tahulated below:

\section{SUBMITTAL}

DATE

$2-10-78$

$2-16-78$

$2-24-78$

$2-28-78$

$$
\text { TO }
$$

J. Clark, NASA/MSFC

J. C lark, R. Joeckel (JBA)

and L.F. Borns

J. Clark and Mueller Associates

J. Clark

\section{SUBJECT}

SHAC Motor and Electronic Controller System Review Material

Las Vegas si te ISRI, Revision C

Allaire State Park Site ISPI, Revision A

Houston Site Storage Loop Expansion Tank Analys is Results 
The analysis of the expansion tank volume for the 75-ton system storage tank was completed in February. Evaluation of preliminary heat pump subsystem test results was begun.

\section{SYSTEM DEVELOPMENT}

The activities reported below involve heat pump component design, fabrication and testing, and heat pump package development.

\section{Component Design, Fabrication and Test}

1. Turbomachine

(a) 3-Ton Unit

Unit No. I has been installed and tested at Dunham-Bush in the heating mode. Unit/system performance was low compared to data accumulated in the system at AiResearch. The difference is attributed to ducting differences at the compressor inlet and outlet. These ducts are being modified at Dunham-Bush.

Unit No. 2 is installed in the system at AiResearch and testing will commence in March using a production controller. Testing with the prototype controller has been stopped.

Unit No. 3 is being fabricated and will be ready for test in March. Unit No. 4 has been removed from "stop" and placed on a low priority status.

(b) 25-Ton Unit

The unit scheduled for shipment to Dunham-Bush for test is assembled and ready for final testing. If testing is successful, the unit will be available for shipment by mid-March. status.

Unit No. 2 has been removed from "stop" and placed on a low priority

(c) 75-Ton Unit

Unit No. $I$ is assembled and testing is approaching completion. The unit will be shipped in mid-March. Unit No. 2 is 80 percent complete. The rotor is being ground prior to shrinking of the sleeve.

\section{Motor Controller}

\section{(a) 3-Ton Controller}

Thermal problems were encountered during system testing at Dunham-Bush. A fan is being installed on all 3-ton controllers to meet the thermal requirements. Controllers will be tested at an ambient temperature of $85^{\circ} \mathrm{F}$ for 4 hours to assure thermal integrity of the controller. The second 3-ton production controller is now complete and testing is in progress. The third 3 -ton production controller is 75 percent complete. The fourth

$$
B-3
$$


unit has been removed from "stop" and placed on a low priority status.

\section{(b) 25-Ton Controller}

Fabrication and testing of the 25-ton production controller is complete. This unit will be tested for 4 hours at maximum speed and load with its cover installed to assure thermal integrity. The second unit has been removed from "stop" and placed on a low priority status.

(c) 75-Ton Controller

Fabrication of the 75-ton controller is complete and testing is in progress. The control electronics have been 100 percent tested with a 25-ton motor. The start commutator has been tested with the 75-ton motor and performs in accordance with design goals. Further testing of this commutator is in progress.

3. System Controller

Five system controllers have been completed and will be shipped to Dunham-Bush as the heat pump subsystems become available for test.

4. R-11 Liquid Pump

(a) 3-Ton Unit in March.

Three pump units have been ordered; delivery is scheduled for early

(b) 25-Ton Unit

The 25-ton, motor was rewound for 3-phase 440 volt, $60 \mathrm{~Hz}$ power in lieu of single-phase 115 volt, $60 \mathrm{~Hz}$ power. Preliminary pump performance data was identical for both windings. The endurance run was temporarily discontinued while the gages and flowmeters were removed from the loop for calibration.

Heat Pump Design, Fabrication and Test

1. Design

New requirements have been submilled to Dunham-Bush for the water pumping needs for the 75-ton heat pumps to be installed in Las Vegas and Houston. Pumps have been selected to match the requirements. Piping drawings have been revisent to accommodate the latest pumps.

\section{Test Activities}

The 3-ton heat pump (less its RII pump) was connected to a $2000 \mathrm{cfm}$ wind tunnel, to a $208 \mathrm{v}$ power source and to a hot water source. Airflow was set at $1200 \mathrm{cfm}$; no effort was made to control the inlet air temperature. Ambient was approximately $75^{\circ} \mathrm{F}$. Heat source water was circulated at approximately $90^{\circ} \mathrm{F}$ in let temperature to the evaporator boiler. All control was manual with the exception of the expansion valve. The machine was started and the speed adjusted at $60,000 \mathrm{rpm}$. 
The speed of the compressor was increased $78,000 \mathrm{rpm}$ and then to $81,500 \mathrm{rpm}$. Before the system could stabilize, a transistor overheated and burned out, shutting down the machine.

While the motor control was being repaired, the $R 11$ four-way reversing valve was checked out in a bench test. With a 25 psi differential, the valve reversed readily. No problems in reversing were encountered down to 12 psi differential. However, at $10 \mathrm{psi}$ differential, the valve would not reverse.

Additional ventilation was provided for the transistors in the motor controller by cutting $7 \mathrm{in}$. square holes in the bottom of the control cabinet directly beneath the transistors and in the top directly over the transistors. The repaired motor controller was reinstalled in the cabinet and reconnected to the machine. Thermocouples were cemented to the heat sink close to the first transistor that failed and in the inlet and outlet ventilation holes.

For initial têsts, the control cabinet door was left open and air from a blower was directed on the transistors to keep them cool. This maintained the heat sink at $120^{\circ} \mathrm{F}$. Several adjustments were made at the expansion valve and best performance seemed to be obtained with the valve set for minimum superheat. Data was then collected with various combinations of compressor speed and boiler water temperatures. Forced air was directed at the motor controller during most of these tests. The machine was shut down at the end of these tests on February 22, 1978.

When the heat pump was restarted, the reversing valve shifted readily to the heating mode. However, the re was some surging. Before the exact cause was determined, a manually held probe was inadvertently placed on a transistor, shorting it out and causing shutdown. This concluded testing for the month until repairs could be made.

Although abbreviated, test accomplishments were significant. Freon. inventory was established with minimal effort. The expansion valve functioned very satisfactorily and projections of the heat pump performance parameters were good. 


\section{Sixteenth Monthly Status Report \\ Data Requirement No. 500-11}

\section{SOLAR HEATING AND COOLING SYSTEMS DESIGN AND DEVELOPMENT}

Contract NAS8-32091

76-13110(16)

April 10, 1978

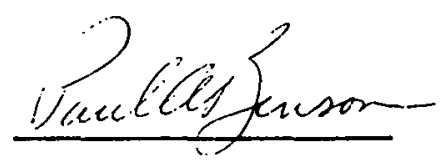

P. A. Benson

\section{Prepared for}

George C. Marshall Space Flight Center

National Aeronautics and Space Administration

Marshall Space Flight Center

Huntsville, Alabama 35812

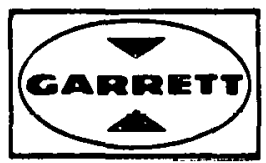

AIRESEARCH MANUFACTURING COMPANY

OF CALIFORNIA

$$
C-i
$$




\section{INTRODUCT ION}

This is the sixteenth monthly status report prepared by AiResearch Manufacturing Company of California under Contract NAS8-32091 for the National Aeronautics and Space Administration Marshall Space Flight Center (MSFC). The report summarizes activities from March 1, to March 31, 1978.

For simplicity in reporting, activities are reported by subject matter rather than by WBS item number.

MEETINGS, REVIEWS, AND MAJOR EVENTS

Activities during March were as follows:

- A site review meeting was held at the Lawrenceburg, Tenn., site at mid-month. Paul Benson of AiResearch attended.

- A program review meeting was held at AiResearch from March 29 through April 4, 1978 ( 5 work days) with Mr. James Clark of NASA in attendance.

PROGRAM PLANNING AND CONTROL

\section{Site Activities}

Last month, program control activities were concentrated on cost reduction measures. All activities with the exception of instrumentation planning and program coordination were abbreviated. This month, further cost cutting procedures were instituted in the method of reporting site activities. At the request of Mr. James Clark of NASA, site and site equipment status charts will henceforth be tranismitted informally between AiResearch and NASA as often as necessary to monitor the system accurately.

\section{Program Documentation}

The following documents were prepared in accordance with the requirements of Appendix $A$ of the Statement of Work:

a. Fifteenth Monthly Status Report 76-13110(15), dated March 10, 1978 (DR500-11).

b. $\therefore$ Quarterly Contractor Financial Management Report (DR500-27)

Other publications were submitted during March to the parties listed as tabulated belnw: 
Submittal

Date

$3-3-78$

$3-6-78$

$3-7-78$

$3-8-78$

ANALYS IS

Evaluation of preliminary heat pump subsystem test results obtained in February is continuing.

\section{SYSTEM DEVELOPMENT}

The activities reported below involve heat pump component design, fabrication and testing, and heat pump package develupulut.

Component Design, Fabrication and Test

1. Turbomachine

\section{(a) 3-Ton Unit}

The month was spent attempting to test the cooling mode of operation. The freon pump would not operate properly at the system temperature and pressure levels. Subcooling was inadequate. A pump with a modified inlet was installed and also found inadequate. System ducting changes were made and tested, each of which helped, but were still not totally adequate. A second pump modification was made to reroute the pump cooling freon away rrum the pump inlet. This is associated with a plumbing change. Testing of this change will be complete the first week of April.

All cooling system tests should be concluded by the second week of April and units 2 and 3 should be avallable for shipment to Dunham-Bush by mid April.

\section{(b) 25-Ton Unit}

Heating system testing at $40,000 \mathrm{rpm}$ is being conducted and should be complete by the first week in April. It has been proven at 40,000 rpm (on two test units) that a comblnatiun of magnetic rotor centrifugal growth in association with thermal growth and shaft runout causes the rotor to hit the stator. 
The solution is to increase the rotor radial clearance from 0.010 to 0.020 inches. This fix is underway. In the interim, a unit in the original configuration is being tested with a speed limitation of 25,000 rpm. This unit will be sent to. Dunham-Bush to allow testing in both the heating and cooling modes. The unit should be available at Dunham-Bush prior to 5-1-78.

(c) 75-Ton Unit

The first unit has been successfully tested to $21,000 \mathrm{rpm}$. Minor controller modifications are required before running at the maximum speed of $24,000 \mathrm{rpm}$. These modifications and tests should be complete within a week. Tests have been run on both air and freon.

It is allicipaled that all test will be complete within 2 weeks and the unit shipped to Dunham-Bush for system testing. Unit No..2 should be available by May 1, 1978 .

\section{Motor Controller}

\section{(a) 3-Ton Controller}

Controller No. I has been modified to improve its thermal characteristics: A fan was installed and the controller was operated at maximum chopper load with the cover installed for 4 hours.

Fabrication and testing of Controller No. 2 is now 100 percent complete while fabrication of Controller No. 3 is 80 percent complete.

\section{(b) 25-Ton Controller}

Interface testing of this controller is continuing. The motor has been operated at maximum speed and load; however, due to mechanical problems in the motor, the required data points for the compressor could not be obtained.

(c) 75-Ton Controller

Fabrication of No. I controller is 100 percent complete. The 75-ton motor has been operated up to 80 percent of maximum speed with no shaft load. Due to lack of arlequate cooling, cxccssive motor heating resulted. A cooling system using freon was installed and the motor was again tested. Due to mechanical problems, however, the motor had to be returned for rebuilding.

Controller No. 2 is 90 percent complete.

\section{System Controller}

Five system controllers have been completed and are being shipped to Dunham-Bush as the heat pump subsystens becune avallable for test. 


\section{R-11 Liquid Pump}

\section{(a) 3-Ton Unit}

Three pump units were delivered in March. One has been installed in the AiResearch subsystem test loop. (Refer to Section I.)

\section{(b) 25-Ton Unit}

The endurance test of the rewound 3-phase, 440 volt, $60 \mathrm{~Hz}$ power prototype pump motor was resumed, but was interrupted again when the test rig was required for acceptance testing of the 3-ton No. I pump. Ninety percent of the hardware for the development units has been received.

Heat Pump Design, Fabrication and Test

\section{Design}

Numerous piping changes and repositioning of the check and reversing valves were necessary as a result of tests of the 3 -ton heat pump in February. These changes were incorporated in the drawings.

The Crane Company (the supplier of the R-!l pump) recommended a different pump than previously considered. This required revision of some of the refrigerant piping.

\section{Prototypes}

The revisions noted above were made on the 3-ton prototype heat pump being tested. The three manifolds on the finned tube evaporator/condenser coil were divided into four sections (at the request of AiResearch) and the expansion valve was equipped with a twelve-tube distributor.

Components, with the exception of the heat cxchangers and turbocompressors have been received for the $\overline{75}$-ton heat pumps. The hed exchangers were due in late March.

\section{Testing}

Tests will resume in April on the 3-ton package.

\footnotetext{
$\$$ U.S. GOVERNMENT PRINTING OFFICE 1978-640.081/318 REGION NO. 4
} 